G. Deby-Dupont

C. Deby

M. Lamy

\section{Neutrophil myeloperoxidase revisited: it's role in health and disease}

Die Rolle der Myeloperoxidase in Gesundheit und Krankheit. Eine Neubewertung

Zusammenfassung Die menschliche Myeloperoxidase (MPO; EC 1.11.1.7) ist eine spezifische Haem$\left(\mathrm{Fe}^{3+}\right)$-Peroxidase, welche hochkonzentriert in den azurophilischen Granula der Neutrophilen vorkommt. Ihre Aminosäure und genomische Sequenz wurde bereits geklärt, und rekombinierte MPO wird inzwischen aus genetisch-manipulierten Säugerzellen hergestellt. Diese Peroxidase hat eine einmalige Chlorinationsaktivität, welche Hypochlorsäure ( $\mathrm{HOCl}$ ) aus Wasserstoffperoxid und Chloridanionen, aber auch aus Chlor und monoatomarem Chlor generie-

Eingegangen: 3. September 1998

Akzeptiert: 4. Januar 1999

Diese Arbeit basiert auf einem Beitrag im Yearbook of Intensive Care and Emergency Medicine 1998, edited by J.-L. Vincent, Springer-Verlag 1998

G. Deby-Dupont $(\bowtie) \cdot C$. Deby $\cdot$ M. Lamy Centre for the Biochemistry of Oxygen Institut de Chimie, B6a

Domaine Universitaire du Sart Tilman

B-4000 Liège

e-mail: gdeby@ulg.ac.be

G. Deby-Dupont · M. Lamy

Department of Anaesthesia and Intensive

Care Medicine

Domaine Universitaire du Sart Tilman, B35 B-4000 Liège ren kann. Durch eine Interaktion mit anderen Neutrophilenzymen und Reaktion mit den Produkten der Neutrophilaktivierung produziert MPO auch andere reaktive Sauerstoffabkömmlinge (Singlett-Sauerstoff, das Hydroxylradikal, Nitrosyl und Nitrylchlorid...). In Phagolysosomen bewirkt MPO zusammen mit der NADPH-Oxidase und Proteasen die Zerstörung der ingestierten Organismen, indem es sich an die Wände der Mikroorganismen bindet und $\mathrm{HOCl}$ vor Ort produziert, welches besonders gegen die Polysaccharidkapseln aktiv ist. Die MPO-Aktivität beeinflußt die Übermittlung des Zellsignals (Aktivierung von NF- $\kappa \mathrm{B}$, Chlorination der Tyrosylreste auf essentiellen Enzymen ...) und moduliert verschiedene Funktionen der Zellen: es vermindert die Killeraktivität der NT-Lymphozyten und verstärkt, nach Internalisation die mikrobielle Aktivität der Makrophagen. MPO wird von Endothelzellen aufgenommen. Ein MPO-Mangel stellt die häufigste Form des NeutrophilLyosom-Enzymmangels dar, tritt aber meistens ohne eine offensichtlich erhöhte Anfälligkeit gegen Infektionen oder eine veränderte Entzündungsantwort auf. MPO wird für die Oxidierung und Chlorination von niedrigdichten Lipoproteinen, welche in der frühen Phase der Atherosklerose eine Rolle spielen, verantwortlich gemacht. In von übermäßiger und unkontrollierter Entzündung charakterisierten Erkrankungen kann
MPO ins extrazelluläre Milieu freigesetzt werden, wo es zytotoxisch auf benachbarte Zellen wirkt und Gewebe und Proteine oxidiert (Thioloxidierung, Oxidierung und Chlorination von Lipiden und Aminosäuren ...). Außerhalb der Neutrophilen wird die MPO-Aktivität rasch durch Proteine inhibiert, aber aktives MPO wird auch in der broncho-alveolären Spülflüssigkeit bei Patienten mit akuter Lungenverletzung gemessen. Dieses spezifische Enzym entwickelt daher eine Doppelrolle, sowohl hinsichtlich der essentiellen Hostprotektion, wenn es in Phagozyten wirksam ist, als auch von Hostschäden, wenn es in das extrazelluläre Milieu freigesetzt wird.

Schlüsselwörter Myeloperoxidase Oxidation - Entzündung

Summary Human myeloperoxidase (MPO; EC 1.11.1.7) is a specific heme $\left(\mathrm{Fe}^{3+}\right)$ peroxidase, present in high concentrations in the azurophilic granules of neutrophils. Its amino acid and genomic sequences have been elucidated, and recombinant MPO is produced from genetically engineered mammalian cells. This peroxidase has the unique activity of chlorination, generating hypochlorous acid $(\mathrm{HOCl})$ from hydrogen peroxide and chloride anion, but also chlorine and monoatomic chlorine. By interacting with other enzymes of neutrophils and reacting with the products of neutrophil activation, MPO 
also produces other reactive oxygen species (singlet oxygen, hydroxyl radical, nitrosyl and nitryl chloride, etc.). In phagolysosomes, MPO acts together with NADPH oxidase and proteases for the destruction of the ingested organisms, by binding to the microorganism walls and producing locally $\mathrm{HOCl}$, which is particularly active against the polysaccharidic capsules. MPO activity influences the transduction of the cellular signal (activation of NF- $\kappa \mathrm{B}$, chlorination of tyrosyl residues on essential enzymes, etc.) and modulates the functions of cells: it decreases the killer activity of NT lymphocytes and, after internal- ization, it enhances the microbial activity of macrophages. MPO is taken up by endothelial cells. MPO deficiency is the most common neutrophilic lysosomal enzyme deficiency, but usually without apparent increased susceptibility to infection or altered inflammatory response. MPO has been recognized to be responsible for the oxidation and chlorination of low density lipoproteins, contributing to the early stage of atherosclerosis. In disease with excessive and uncontrolled inflammatory reaction, MPO can be released in the extracellular milieu where it becomes cytotoxic for neighboring cells (oxidant stress) and oxidizes tissues and proteins (thiol oxidation, oxidation and chlorination of lipids and amino acids, etc.). Out of the neutrophil, the activity of MPO would be quickly inhibited by proteins; however, active MPO has been measured in broncho-alveolar lavage fluids from patients with acute lung injury. This specific enzyme, thus, presents a double role of essential host protection when acting into the phagocytes and of host damage when released in the extracellular milieu.

Key words Myeloperoxidase Oxidation - Inflammation

\section{Introduction}

The inflammation response is an important constitutive defense mechanism against microbial infection. This response focuses the circulating antimicrobial factors on the site of infection, including the phagocytic cells, of which the neutrophils are dominant. They are the first to arrive by diapedisis, allowed by increased capillary permeability and chemotactic stimuli. After adherence, the microorganism is ingested by engulfment, forming the phagosome, which collides into the cytoplasm with lysosomal granules and fuses with the lysosomal membrane to form the digestive vacuole, the phagolysosome. The killing and lysis then start by oxygen-dependent and independent events. The oxygen-independent microbicidal activity is linked to cationic proteins, lactoferrin, and hydrolytic enzymes, and the oxygen-dependent way is linked to the activity of membrane bound NADPH oxidase acting in concert with myeloperoxidase (MPO) [54]. This enzyme, specific of neutrophil, is of primary importance in the killing of microorganisms with polysaccharidic capsules that protect them against the proteolytic and hydrolytic machinery of phagocytes.

Characteristics of MPO and mechanisms of its enzymatic activity

Myeloperoxidase (EC 1.11.1.7), a heme-containing peroxidase, is present in high concentrations in the primary (azurophilic) granules of the polymorphonuclear leucocytes (PMN) $[8,103]$. MPO comprises 2 to $4 \%$ of the neutrophils by weight. This enzyme is also present in the granules of monocytes, but in lower amounts ( $0.9 \%$ in weight), and these cells gradually lose their MPO during their matura- tion into macrophages. In the 1970s, new purification procedures and unlimited cell material (human myeloid leukemic cell lines) increased the yield and purity of human MPO allowing one to study in more details the structure, biosynthesis, and function of the enzyme [7, 77, 103]; its amino acid sequence has been completely elucidated [67], and the gene of MPO has been isolated, cloned, and characterized [70]. The human MPO gene represents a simple gene $(14 \mathrm{~kb})$ located on the long arm of chromosome 17 [42, 106, 117]. It is composed of 12 exons and 11 introns with a single transcription initiation site [70]. The complete nucleotide sequence of human MPO gene has been elucidated [45]. The basal promoter (a 594-bpairs DNA sequence) has been located in the proximal 5 -flanking region of the gene with 7 discrete nuclear protein binding sites [118]. Transcriptional cis-elements, involved in the MPO gene expression, have been identified in the introns 7 and 9 [115]. An upstream (distal) DNA fragment was also identified in the MPO gene, with enhancer activity for the endogenous basal MPO promoter. This enhancer appears likely to play a role in the control of MPO transcription during myeloid differentiation [6].

The MPO gene is expressed specifically in immature myeloid cells, and its expression is tightly regulated [47, 104]. Granulocyte-colony stimulating factor (G-CSF) would play a role in the MPO gene expression as a G-CSF-responsive element (GRE) was found in the MPO gene, around 800-bpairs upstream from the transcription initiation site [78]. A specific nuclear factor (NF/G-CSF), identified with an ubiquitous transcription factor NF-Y, would bind to this element. The expression of MPO gene is confined to the first stages of myeloid differentiation, peaking at promyelocyte stage and undetectable in mature granulocytes and monocytes, so that accumulation of MPO messenger RNA occurs only at the late myeloblastic and promyelocytic stages of myeloid differentiation. MPO mRNA 
synthesis ceases at the end of the promyelocyte stage of myeloid maturation [118].

As a consequence of this fundamental research on MPO gene, human recombinant MPO is now produced from genetically engineered mammalian cells as a glycosylated monomeric precursor with enzymatic activity and strong similarity to the native human enzyme [43, 69].

MPO is a myeloid cell-specific enzyme, synthesized during the promyelocytic stage; at this stage, the enzyme is present in cytoplasm and would also be present in the nucleus as reported by Murao et al. [71], but this observation was not confirmed by subsequent studies. The first form of the enzyme is a single 75 to $80-\mathrm{kD}$ protein, which is modified in the endoplasmic reticulum (ER) by N-linked glycosylation followed by deglucosylation to generate the 90-D apopro-MPO. This apopro-MPO is then associated transiently with the molecular chaperones calreticulin and calnexin for maturation and processing. After heme insertion, when coming out of the Trans Golgi network, proPMO is processed to its mature form by proteolytic processing in a post-ER, pregranule compartment $[8,20]$. The precursor is trimmed into 2 peptide subunits of 59 and 13.5 $\mathrm{kD}$, the heavy and light chains which are linked by a disulfide bond to form a single heterodimer. Two heterodimers are linked by an additional disulfide bond to form the mature enzyme (carrying 2 identical prosthetic groups) that is stored in azurophilic granules [2, 7, 75]. A fraction of normal proMPO enters the secretory pathways where it is modified in the Golgi complex en route to extracellular release [20].

At least, 3 isoenzymes are present in neutrophils [67, $80,81,114]$. The structure of the prosthetic group of MPO has been elucidated; the heme structure (carrying a Fe ${ }^{3+}$ ion) is a derivative of protoporphyrin IX, with covalent bonds between 2 pyrrole rings and three different amino acid residues, the aspartate and glutamate bonds which are characteristic of all mammalian peroxidases, and a methionine bond (via a sulfonium linkage), which is unique to MPO and responsible of its chlorination properties [27]. Mutation of this methionine residue results in the loss of the chlorinating activity [56]. The incorporation of the heme group precedes the maturation process, so that the precursor is enzymatically active $[4,102]$.

MPO is a member of the mammalian family of peroxidases, which also includes lactoperoxidase, eosinophil peroxidase, and thyroid peroxidase. But MPO differs from the other compounds of this family by its unique activity of chlorination (together with its peroxidase activity), which is the ability to catalyze the oxidation of chloride to hypochlorite. The complete MPO system is formed by the enzyme, $\mathrm{H}_{2} \mathrm{O}_{2}$, and an oxidizable cofactor, such as a halide. The $\mathrm{H}_{2} \mathrm{O}_{2}$ is formed during the respiratory burst from $\mathrm{O}_{2}$ via the superoxide anion $\left(\mathrm{O}_{2}^{\dot{*}}\right)$ intermediate, and the halide is often chloride as the most abundant in vivo. But MPO also uses fluoride, bromide, and iodide. Its reactivity with iodide anion $\left(\mathrm{I}^{-}\right)$would be higher than with $\mathrm{Cl}^{-}[76,101]$, but the relative rarity of $\mathrm{I}^{-}$in vivo limits this iodination activity of MPO.

Ferric MPO forms a short-lived compound I with $\mathrm{H}_{2} \mathrm{O}_{2}$ (Fig. 1). A recent paper proposed that this compound I has the structure of a biradical molecule, with a ferryl-heme iron and a radical center located on an amino acid residue (the $\pi$-cation radical) [25]. The iron of this compound I would be $\mathrm{Fe}^{\mathrm{IV}}$, and not $\mathrm{Fe}^{\mathrm{V}}$ as previously presented. This compound I is highly reactive with halides, generating hypochlorous acid $(\mathrm{HOCl})$ and regenerating $\mathrm{MPO}$ in its ferric native state. The optimum for MPO activity occurs at acidic $\mathrm{pH}$ (approximately 5.5), but the enzyme remains active over a wide range of $\mathrm{pH}$. MOP activity is inhibited by high concentrations of $\mathrm{H}_{2} \mathrm{O}_{2}$. Compound I can also react
Fig. 1 Mechanisms of myeloperoxidase (MPO) activity. $\mathrm{Fe}^{\mathrm{II}}$, $\mathrm{Fe}^{\mathrm{III}}, \mathrm{Fe}^{\mathrm{IV}}$ : oxidation states of iron in heme; P: protein moiety of MPO; $\mathrm{P}^{+}: \pi$-cation radical centered on an aminoacid residue of the protein; $\mathrm{Fe}^{\mathrm{VI}}=\mathrm{O}$ : ferryl heme iron; $\mathrm{O}_{2}^{-}$: superoxide anion; $\mathrm{H}_{2} \mathrm{O}_{2}$ : hydrogen peroxide; HOCl: hypochlorous acid; $\mathrm{AH}^{-}$: electron donor molecule (ascorbate?); $\mathrm{AH}^{-}$: radical state of the electron donor (ascorbyl?)

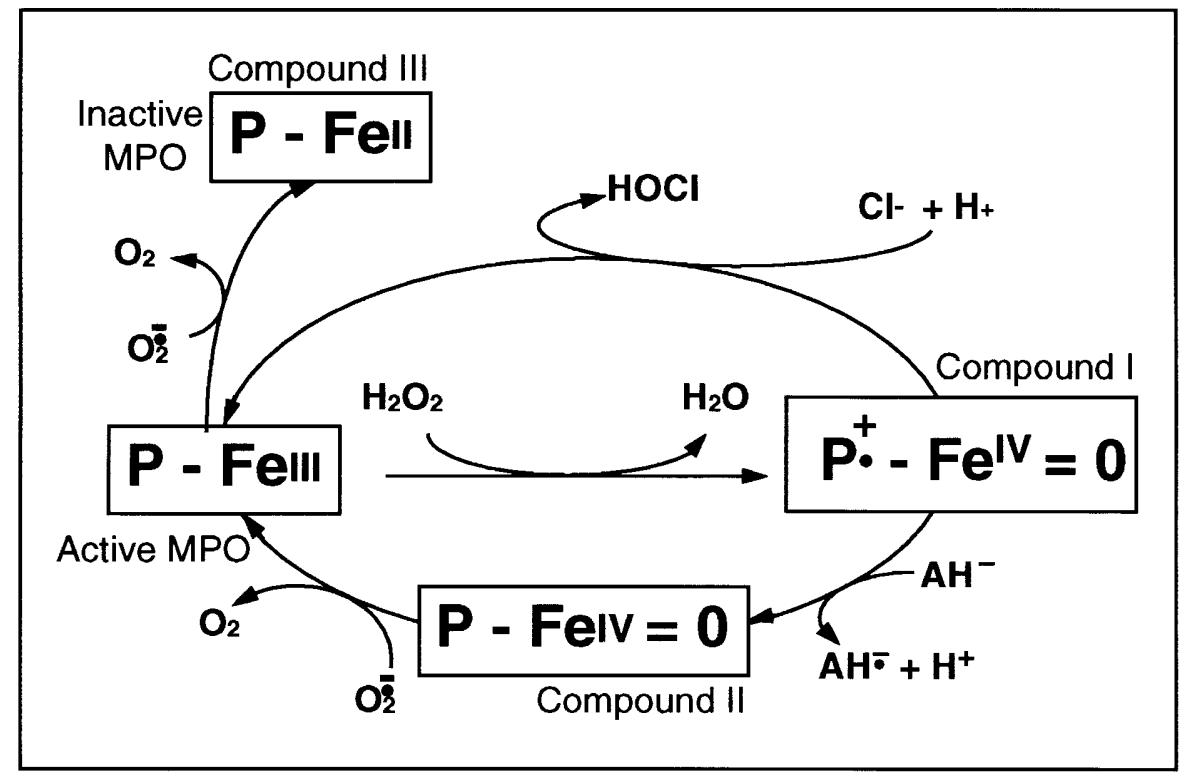


Fig. 2 Active oxidant species produced by the activity of myeloperoxidase (MPO) in the phagolysosome and interactions with NADPH oxidase and NO synthase activities: $\mathrm{O}_{2}^{-}$: superoxide anion; $\mathrm{H}_{2} \mathrm{O}_{2}$ : hydrogen peroxide; HOCl: hypochlorous acid; ${ }^{\circ} \mathrm{OH}$ : hydroxyl radical; ${ }^{1} \mathrm{O}_{2}$ : singlet oxygen; $\mathrm{Cl}_{2}$ chlorine; ${ }^{\circ} \mathrm{Cl}$ : nascent chlorine (monoatomic); NO: nitric monoxide; $\mathrm{ONOO}^{-} / \mathrm{ONOOH}$ : peroxynitrite/peroxynitrous acid; $\mathrm{NO}_{2}^{-}$: nitrite anion; $\mathrm{NOCl}$ : nitrosyl chloride; $\mathrm{NO}_{2} \mathrm{Cl}$ : nitryl chloride; ${ }^{\circ} \mathrm{NO}_{2}$ : nitrogen dioxide

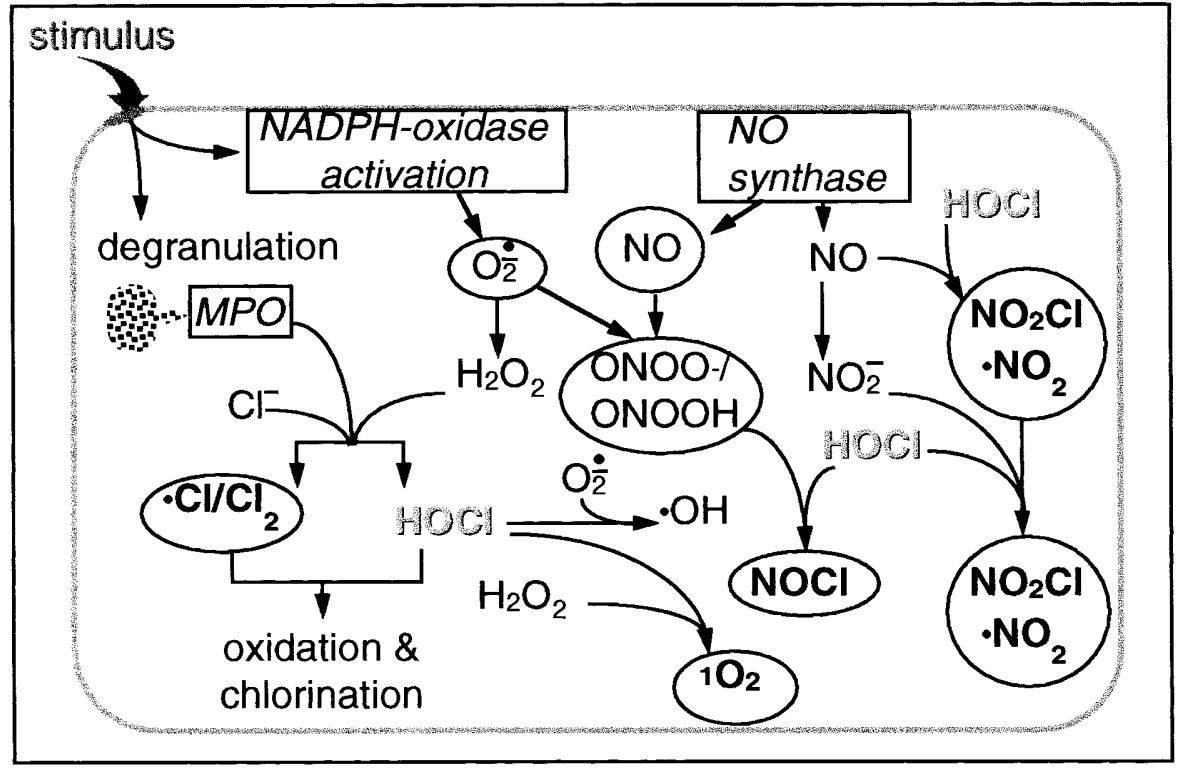

with other electron donors to be converted to compound II, a ferryl heme iron molecule which has lost its amino acid centered radical and is inactive in reacting with halides (Fig. 1). Superoxide anion could be one of these electron donors, but ascorbic acid, abundant in neutrophils, is another candidate for this reductor role. The compound II returns to the native ferric heme enzyme by a one-electron reduction (possible role of $\mathrm{O}_{2}^{-}$). It also appears that the native ferric enzyme could be reduced to inactive ferrous MPO (compound III) by $\mathrm{O}_{2}^{-}[49,51,112]$ This reaction would occur in the phagolysosome, at the beginning of phagocytosis, when the $\mathrm{pH}$ value is still alkaline or neutral, allowing a maximal activity of NADPH oxidase with an important production of $\mathrm{O}_{2}^{-}$. King et al. [51] demonstrated that during phagocytosis about $14 \%$ of MPO contain was released in the medium, about $17 \%$ in the phagolysosome, and $68 \%$ remained in the granules and that the MPO that was released in the medium was inactivated. The enzyme was mostly inactivated by destruction of its ironcontaining prosthetic group (compound III), and it seemed that the agent responsible of this inactivation was $\mathrm{O}_{2}^{-}$. The proteic structure of the enzyme was unaltered (absence of proteolysis), and there was no binding that could account for the loss of MPO activity. However, it still remains uncertain whether this compound III can be reactivated to the native active ferric MPO. Many inhibitors of MPO are known, but they are generally not specific to MPO but to heme enzymes, and most of them are toxic (such as azide).

Oxidants species produced by the enzymatic activity of MPO (Fig. 2)

The reactive oxidants generated by phagocytes are of central importance in the host defense, in tumor surveillance, and in inflammation. During the respiratory burst, phagocytes generate $\mathrm{O}_{2}^{-}$, which dismutates into $\mathrm{H}_{2} \mathrm{O}_{2}$ [54]. MOP catalyses the conversion of $\mathrm{H}_{2} \mathrm{O}_{2}$, and uses chloride anion $\left(\mathrm{Cl}^{-}\right)$as the electron donor, to produce the primary and most important germicidal oxidant, hypochlorous acid [110]. MPO is the only human enzyme that produces hypochlorite under physiological conditions. This reagent is a strong oxidant, able to chlorinate amine groups and convert them to chloramines. Some of these chlorinated compounds are also considered as potent oxidants. But it seems that MPO can also chlorinate aromatic ring of tyrosyl residues by a mechanism that is not completely elucidated; this chlorination of the tyrosyl residue could happen via an intermolecular reaction of a chloramine (formed by the activity of $\mathrm{HOCl}$ ) with the aromatic ring of tyrosine [21]. However, it also appears that chlorine $\left(\mathrm{Cl}_{2}\right)$ and even monoatomic chlorine (nascent chlorine) are produced in equilibrium with $\mathrm{HOCl}$, executing oxidation/halogenation reactions that have previously been attributed to $\mathrm{HOCl} / \mathrm{ClO}^{-}$[39] . This production of chlorine is favored by the acidic $\mathrm{pH}$ of the phagolysosome and would implicate the possibility of radical mechanisms as proven by the synthesis of dityrosine by human neutrophils [40]. This radical production would occur when MPO uses compounds other than $\mathrm{Cl}^{-}$as the electron donor for the reduction of $\mathrm{H}_{2} \mathrm{O}_{2}$. These compounds are converted into radical species that can initiate lipoperoxidation or crosslinking of proteins. Whatever the mechanism of MPO activity (production of $\mathrm{Cl}^{\circ}, \mathrm{Cl}_{2}, \mathrm{ClO}^{-}$ or chloramines), chlorinated low density lipoproteins [36], chlorinated sterols [38], and chlorinated tyrosyl residues [21] are formed by MPO activity. These chlorinated tyrosines have been presented as specific markers of MPO activity in inflammatory tissue damage [21].

Other active oxygen species appear to be produced by the activity of MPO. One of them is singlet oxygen $\left({ }^{1} \mathrm{O}_{2}\right)$, 
an excited form of oxygen, which presents a high excess in energy rendering it able to react with most organic compounds. Singlet oxygen is easily produced by the reaction of $\mathrm{H}_{2} \mathrm{O}_{2}$ with $\mathrm{HOCl}, 2$ compounds which can simultaneously be produced by activated neutrophils. But, if the synthesis of ${ }^{1} \mathrm{O}_{2}$ is theoretically possible during MPO activity and has been demonstrated under in vitro conditions, the reality of its production in vivo is far from being undoubtly demonstrated, so that the production of ${ }^{1} \mathrm{O}_{2}$ by stimulated neutrophils remains a matter of discussion [46].

$\mathrm{HOCl}$ could also oxidize superoxide anion, becoming a source of radical species, $\mathrm{OCl}^{\circ}, \mathrm{Cl}^{*}$, and the hydroxyl radical $\left({ }^{\circ} \mathrm{OH}\right)$ that could thus be produced in a way different from the Fenton reaction $\left(\mathrm{H}_{2} \mathrm{O}_{2}\right.$ in presence of complexed iron) and independent of the presence of metal ions [11, $50,85]$.

Neutrophils produce $\mathrm{O}_{2}^{-}$and nitrogen monoxide ( $\mathrm{NO}$ ), 2 radical species that react at a diffusion-controlled rate to produce peroxynitrite $\left(\mathrm{ONOO}^{-}\right)$, a strong oxidizing agent [13]. MPO activity interferes with this ${ }^{\circ} \mathrm{NO}$ and $\mathrm{ONOO}^{-}$ production [28]. $\mathrm{HOCl}$ can oxidize ${ }^{\circ} \mathrm{NO}$ giving ${ }^{\circ} \mathrm{NO}_{2}$ (a nitrating agent), but cannot efficiently compete with the reaction of ${ }^{\circ} \mathrm{NO}$ with superoxide anion to yield peroxynitrite $\left(\mathrm{ONOO}^{-}\right)$. With $\mathrm{ONOO}^{-}$, however, $\mathrm{HOCl}$ can react and produce nitrosyl chloride $(\mathrm{NOCl})$ at the origin of nitrosylations (by decomposition into $\mathrm{Cl}^{-}$and ${ }^{\circ} \mathrm{NO}$ ) and generation of mutagens or promutagens [57]. $\mathrm{HOCl}$ would also react with nitrite $\left(\mathrm{NO}_{2}^{-}\right)$, the autoxidation product of $\mathrm{NO}$, forming reactive intermediate species capable of nitrating phenolic substrate such as tyrosine at physiological $\mathrm{pH}$. These reactions would occur by the way of radicalar compounds $\left({ }^{\circ} \mathrm{NO}_{2},{ }^{\circ} \mathrm{Cl}\right)$ and transient species similar to nitrylchloride $\left(\mathrm{Cl}-\mathrm{NO}_{2}\right)$ [22]. It also appears that MPO could utilize $\mathrm{NO}_{2}^{-}$and $\mathrm{H}_{2} \mathrm{O}_{2}$ for tyrosine nitration of proteins by a chloride-independent mechanism [92].

The activity of MPO is, thus, responsible for the synthesis of many oxidant species (Fig. 2), which participate in the normal defense of the host and in the complex chemiluminescence that is observed when isolated neutrophils are stimulated in vitro. The use of a specific technique of free radical detection (electron spin resonance with spin trapping) proves that free radicals are produced during MPO activity.

The antimicrobial activity: a beneficial role of MPO in host defense

The exact mechanism by which the MPO- $\mathrm{H}_{2} \mathrm{O}_{2}-\mathrm{Cl}^{-}$system exerts its microbial killing is unknown, but this activity, in relation with non-oxidative microbial activity of neutrophils, is of main importance in the host defense. Neutrophils kill pathogenic microorganisms by sequestration within phagocytic vacuoles (phagolysosomes), where toxic oxygen species are delivered together with granulocytic enzymes. MPO has been proven to be active against many microorganisms by oxidant attack at various sites and in a variety of ways. It appears that one essential step is the binding of the enzyme to the wall of the microorganism with retention of chlorination activity and providing a close contact for oxidative activity. The binding occurs rapidly, with a large number of binding sites per cell [68], and implication of mannan polysaccharides of the target cell wall. This binding also permits the extracellular killing of fungi and parasites that cannot be phagocytosed because of their shape, as demonstrated for MPO binding on Candida albicans [113].

After binding, MPO-mediated killing is mainly dependent on $\mathrm{HOCl}$ production since this molecule reacts with a wide variety of biological compounds, including heme proteins and porphyrins (oxidative bleaching), unsaturated lipids, sulfhydryl groups, iron sulfur centers, reduced pyridine nucleotides, DNA, amino groups. With the amino groups, $\mathrm{HOCl}$ produces chloramines, which themselves are often cytotoxic by breaking peptides bonds and by degradation into toxic aldehydes. With the phospholipids of membranes, $\mathrm{HOCl}$ forms haloamines and halohydrins [12]. The MPO-mediated oxidation of iron-sulfur centers is responsible for the loss of microbial iron and for the destruction of the enzymes of the electron chain transport of bacteria leading to the loss of aerobic respiration and a fall in viability [84, 89]. The MOP activity also damages the membranes, modifying their permeability and allowing leakage of essential cellular compounds. Another consequence of these membrane alterations appears to be the inhibition of cell signalling transmission and arrest of DNA replication [91].

MPO is also a helper for killing of microorganisms by macrophages. MPO is present in low amounts in monocytes, and these cells lose their granule MPO during their maturation into macrophages. In vitro studies demonstrated that human monocytes isolated from blood and cultured until their differentiation into macrophages lost their MPO content and that this phenomenon was correlated with a decreased killing activity on protozoa [61]. Using Pseudomonas aeruginosa, we demonstrated that cultured human macrophages were rapidly overwhelmed by these microorganisms which, despite being incorporated into the phagocytes, remained alive and able to multiply. Their polysaccharidic capsules protected them against the proteolytic and hydrolytic machinery of macrophages. But when we pre-incubated these cultured macrophages with human neutrophil myeloperoxidase, the active enzyme was internalized and restored the killing capacities of macrophages against $P$ seudomonas aeruginosa [66]. Similar observations were made with murine peritoneal macrophages: the addition of exogenous recombinant MPO at physiological concentrations enhanced phagocytosis and killing of Escherichia coli, together with an increase production of reactive oxygen species measured by luminoldependent chemiluminescence [60]. A macrophage mannose receptor, sensible to oxidant stress, seems to be a reg- 
ulator of this exogenous active MPO uptake and delivery to the lysosomal compartment of macrophages [97]. MPO is also taken up by the endothelial cells and the fibroblasts, affording to these cells a self-protection that they normally lack [116].

However, if the microbial killing activity of MPO is largely demonstrated, it appears that in vivo the role of MPO cannot be the key of host defense, since individuals with MPO-deficient neutrophils do not apparently present an increased susceptibility to bacterial infection.

\section{MPO in host damage}

During neutrophil activation and bacteria ingestion, MPO activity mostly remains intracellular, and only around $10 \%$ of MPO is found in the extracellular fluids where it participates in extracellular bacterial killing. Inflammation is, thus, a normal and essential response of the host for its protection against infection, but is also an aspect of pathogenesis resulting in considerable damage to the host when inflammation becomes excessive and uncontrolled, with external degranulation and release of MPO in the external milieu or in close contact with cells and tissues. This excessive activation leads to local oxidant stress, and the oxidant species produced by neutrophils have been implicated in the pathogenesis of diseases ranging from atherosclerosis to ischemia-reperfusion injury and cancer.

\section{Cytotoxicity of $M P O$}

Outside the phagolysosome, MPO is cytotoxic for malignant but also for normal cells. Hemoglobin is oxidized and erythrocytes are lyzed by MPO activity [53, 103]. MPO is also active in the stimulation of platelets, triggering the release of serotonin [103], and in the autoinactivation of neutrophils. These cytotoxic effects have been demonstrated in vitro with the MPO- $\mathrm{H}_{2} \mathrm{O}_{2}-\mathrm{Cl}^{-}$system alone or in combination with other active species produced by stimulated neutrophils. But, a pivotal target for the cytotoxic effects of the MPO system is the endothelium. Exogenous human MPO is taken up by cultured human endothelial cells and conserves its enzymatic activity [65]. After this incorporation, the cells can undergo an oxidative stress providing that $\mathrm{H}_{2} \mathrm{O}_{2}$ is produced intracellularly, as it occurs in ischemia-reperfusion phenomena when the activity of xanthine oxidase is triggered. Under these conditions, the cells are submitted to an oxidant stress with variable degrees of cytotoxicity $[58,65]$. The same oxidant stress (leading to cell death) is observed when neutrophils are stimulated on the surface of cultured endothelial cells. In a model of interactions between cultured endothelial cells and neutrophils, we demonstrated that a close contact between endothelial cells and stimulated neutrophils is not necessary to obtain cytotoxicity: by incubating the cells with the superna-

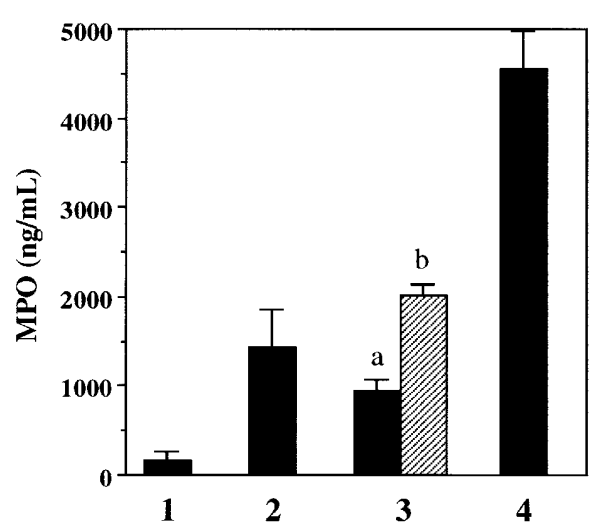

Fig. 3 Myeloperoxidase (MPO) value in critically ill patients. (1) control value in plasma of healthy volunteers $(n=152)$; (2) plasmatic value in trauma (first $24 \mathrm{~h}$ after injury) $(\mathrm{n}=15)$; (3) plasmatic value in cardiac surgery patients; a: directly after heparin administration; b: at declamping (heart reperfusion); (4) plasmatic value in severe sepsis $(n=22)$

tant of stimulated neutrophils, cytotoxicity is observed after 3 hours, which is related to the concentration of the active MPO present in the supernatant.

In vivo, when neutrophils are recruited and activated in an uncontrolled manner, they degranulate close to the endothelium or in organs or tissue that have been reached by the neutrophils after diapedesis. The MPO- $\mathrm{H}_{2} \mathrm{O}_{2}-\mathrm{Cl}^{-}$ system, released by degranulation, would then become the source of local oxidative damage [108]. MPO activity was found in intestinal tissue in ischemia-reperfusion pathologies [3]. This oxidant stress is also encountered in human diseases characterized by excessive inflammatory reaction and neutrophil activation, such as severe sepsis, acute lung injury (ALI), and acute respiratory distress syndrome (ARDS). Using a specific radioimmunological technique, we demonstrated that plasma concentrations of MPO increased in many intensive care patients in whom a leukocyte activation could occur. These increased plasma concentrations of MPO were observed in critically ill patients (trauma, shock, sepsis, acute pancreatitis, etc.). and in cardiac surgery patients (Fig. 3). The highest MPO plasmatic values (up to 100 times the mean normal value) were measured in sepsis and persisted for several days. In trauma, the release of MPO occurs early (in the first few hours after injury) and was concomitant to the release of elastase, another enzyme of neutrophils, indicating a degranulation of these cells in the extracellular milieu [19]. In cardiac surgery, the MPO release was parallel to the increased number of neutrophils and appeared as the consequence of neutrophil stimulation by the complement pathway (activated by contact with the foreign surface of the extracorporeal circulation device) [26]. MPO was also found in the broncho-alveolar lavage fluids of intensive care patients with bronchopneumonia and ARDS, as a witness of the presence of intra-alveolar activated neutrophils, together with 
other products of neutrophil activation (elastase, lactoferrin, etc.) and with oxidant activity of BAL $[15,32,107]$. We recently measured active MPO in BAL of intensive care patients (bronchopneumonia, ARDS), and found a correlation between the MPO levels and the cytotoxicity of BAL on alveolar cells in culture [16].

\section{Inflammatory effects of MPO}

The MPO- $\mathrm{H}_{2} \mathrm{O}_{2}-\mathrm{Cl}^{-}$system is implicated in the inactivation and activation of many enzymes and in the oxidation of many biological compounds (Table 1). $\mathrm{HOCl}$ and other oxidant species react with a wide variety of molecules, including heme proteins and porphyrins (oxidative bleaching), unsaturated lipids, iron sulfur centers, thiols, reduced pyridine nucleotides, DNA, amines, and amino acids, becoming so potentially deleterious $[1,83]$. Nearly all $\alpha$-aminoacids are oxidized to aldehydes by $\mathrm{HOCl}$, and these compounds generated at the site of inflammation become active mediators [37]. Extracellularly, at physiological pH, $\mathrm{HOCl}$ inactivates thiol functions, suppressing the antiproteasic activities of $\alpha_{1}$-proteinase inhibitor and $\alpha_{2}$-macroglobulin $[18,64]$. These two antiproteinases are essential for the control of proteolysis-antiproteolysis balance in plasma. $\alpha_{2}$-Macroglobulin presents a wide range of antiproteolytic activity by complexing many proteases; these complexes being rapidly eliminated by the reticulo-endothelial system. $\alpha_{1}$-Proteinase inhibitor is particularly active against elastase, and its inactivation by oxidation of the active methionine center leads to increased elastolytic breakdown of tissue, which is of pivotal importance when it occurs in the lungs during ALI or ARDS. Oxidized (and thus inactive) $\alpha_{1}$-proteinase inhibitor and free elastase activity have been found in BAL of ARDS patients [15, 100]. Glutathione (GSH) is another important biological target of HOCl. In addition to giving the disulphide (GSSG), which can be recycled by the activity of GSH reductase, $\mathrm{HOCl}$ attack of GSH also gives products identified as internal sulphonamide and thiosulphonate, which are likely to be irreversible, depleting the cell of GSH and compromising the antioxidant defense [111]. The depletion and oxidation of GSH have been described at the level of alveolar epithelial lining fluid in ARDS patients [79]. Fortunately, in plasma many other compounds bearing thiol functions (such as albumin) are present, so that a large excess of oxidants would be required to destroy the thiolbearing proteins and peptides [48].

MPO also acts on the inflammation response by activating latent enzymes, such as the metalloproteinases collagenase and gelatinase. The activation of these enzymes together with the MPO-mediated oxidation of the lysine side chain of elastin leads to the crosslinking of elastine and connective tissue destruction [14, 109]. Active gelatinase was measured in BAL fluids from ARDS patients [87].
Table 1 Cellular and humoral effects of $\mathrm{MPO} / \mathrm{H}_{2} \mathrm{O}_{2} / \mathrm{Cl}$ system

\begin{tabular}{lc}
\hline Target & $\begin{array}{l}\text { Effects } \\
\text { (modulation, damaging or beneficial) }\end{array}$ \\
\hline Cells & \\
- neutrophils & $-\begin{array}{c}\text { cytotoxicity, regulation of active oxy- } \\
\text { gen species production }\end{array}$ \\
$-\begin{array}{l}\text { lymphocytes } \\
\text { (B, T, NK) }\end{array}$ & $-\begin{array}{l}\text { regulation, impairment of functions, } \\
\text { cytotoxicity, signal transduction }\end{array}$ \\
- monocytes/ & alterations \\
macrophages & - regulation of secretion, increase of \\
- platelets & bacterial killing (MPO uptake) \\
- erythrocytes & - increase of activity, cytotoxicity \\
& - cytotoxicity (membrane alteration, \\
- endothelial cells & - cytogotoxicity, alterations of functions, \\
& $\begin{array}{l}\text { increased bactericidal activity } \\
\text { (MPO uptake) }\end{array}$ \\
- tumor cells & - cytotoxicity
\end{tabular}

Microorganisms

cytotoxicity and killing (proteins and iron oxidation, DNA alteration, respiratory protein damage, polysaccharidic capsules destruction, etc.)

Enzymes and soluble mediators

$$
\begin{array}{ll}
\text { - latent collagenases } & \text { - activation } \\
\text { and gelatinase } & \\
\text { - lysosomal enzymes } & \text { - activation } \\
\text { - bacterial toxins } & \text { - oxidation } \\
\text { - chemoattractants } & \text { - oxidation }
\end{array}
$$

Tissue and plasma proteins and peptides

\begin{tabular}{ll} 
- elastine & - lysine oxidation (with cross-linking \\
& of side chains) \\
- antiproteinases: & - inactivation (-SH oxidation) \\
$\alpha_{2} \mathrm{M}, \alpha_{1} \mathrm{PI}$ & \\
- LDL & - lysine and tryptophan oxidation in \\
& Apo-B, cholesterol chlorination \\
- phospholipids & - haloamines and halohydrins formation \\
- GSH & - oxidation \\
- aminoacids in & $-\alpha$-oxidation (into aldehydes), tyrosine \\
peptides & chlorination, dityrosine formation \\
and proteins & (protein bridging) \\
\hline
\end{tabular}

Limiting the MPO activity in diseases with uncontrolled inflammatory response such as infection, ALI, and ARDS, would be useful by using suitable non-toxic compounds, but the known inhibitors are either not specific for MPO such as the thiol or the cyanate $\left(\mathrm{CNO}^{-}\right)$compounds, or not specific for neutrophil MPO such as methimazole, a competitive inhibitor which also blocks thyroid peroxidase. King et al. [51] suggested that the inactivation of MPO by $\mathrm{O}_{2}^{-}$may limit the MPO-mediated damage to host tissues, but the detection of active MPO in BAL would indicate that this inactivation is reversible.

\section{Cell signalling alterations}

Reactive oxygen species are now considered as responsible for the activation of the nuclear factors (NF) of transcrip- 
tion and appear to play the role of second messengers in the induction of gene transcription [95]. They are involved in cellular mutagenesis by the nitrosylating activity of compounds derived from $\mathrm{ONOO}^{-}$. Hydrogen peroxide has been demonstrated to be active in the NF- $\kappa \mathrm{B}$ transcription [55, 93]. This activating role of NF- $\kappa \mathrm{B}$ is also observed by $\mathrm{HOCl}$. MPO, producing $\mathrm{HOCl}$ and reacting with $\mathrm{ONOO}^{-}$ and $\mathrm{NO}_{2}^{-}$to produce nitrosylating and nitrating species is thus responsible for alteration of cellular signalling by nitration of the tyrosyl residues, but also by its chlorination activity.

Tyrosine is an essential residue in many proteins active in cellular signalling, such as the tyrosine kinases and tyrosine phosphatases. The phosphorylation of the tyrosyl residues is a key step in the transmission of signals leading to the activation of the cellular machinery which starts a chain of reactions allowing the NFs to enter the nucleus and trigger mRNA synthesis and protein transcription. The main role of tyrosine kinase is controlled by proteins which dephosphorylate tyrosine kinase, the phosphorylated tyrosine phosphorylases (PTP), which are themselves tyrosine proteins. The nitrosylation and nitration of these tyrosyl residues destroys the normal functions of the proteins and alters the membrane structure when the protein is located in the cell membrane $[93,98]$. It is highly probable that the chlorination of the tyrosyl residues by $\mathrm{HOCl}$ or chloramines would lead to similar destruction of protein function. It also appears that MPO could produce radical species from amino-acid residues, without the intervention of halide or metal, but only in the presence of $\mathrm{H}_{2} \mathrm{O}_{2}$. Tyrosyl radicals could be produced in this manner, leading to the formation of dityrosine species and protein bridges [41], that could have deleterious effects on the normal functions of the enzymes with tyrosine residues involved in the signal transduction. In this perspective, the MPO activity would impair cell signalling, leading to alterations of cellular functions and secretion: inhibition of active mediator production, deregulation of the control of specific protein synthesis, etc. $\mathrm{HOCl}$ and MPO have been demonstrated to act on signalling in the T-lymphocytic cell line [94]. This activation of nuclear transcription factors has different effects, which could be beneficial for host, but also deleterious, particularly when this transcription leads to the synthesis of inflammatory mediators, such as TNF $\alpha$ and IL8, occuring in patients with severe sepsis, acute inflammation, ARDS or systemic inflammatory response syndrome [96].

\section{MPO, modulator of cell functions}

In addition to its role in microbial killing, the activity of $\mathrm{MPO} / \mathrm{H}_{2} \mathrm{O}_{2} / \mathrm{Cl}^{-}$is of importance in modulation of the inflammatory response at the site of tissue damage and in systemic circulation, with beneficial effects but also host damage when the inflammation response is excessive. MPO is transported to the site of infection by the diaped- esis of chemotactically attracted neutrophils and is released by degranulating or dying neutrophils at the site of inflammation reached by the phagocytes. MPO will thus locally catalyze the production of potent oxidant species, able to diffuse in biological structures, and in this way, will affect most of living cells and tissues, modulating the functions of many cells when in close contact with them (Table 1).

\section{Interactions with lymphocytes}

The role of granulocytes and active oxygen species on the activity of lymphocytes has been largely described [95]. In vivo, the activity of natural killer cells in tumor tissues is decreased when they are temporary associated with phagocytes. In vitro, the natural killer activity of lymphocytes displayed a marked decrease when these cells are exposed to stimulated purified neutrophils and monocytes. The $\mathrm{MPO} / \mathrm{H}_{2} \mathrm{O}_{2} / \mathrm{Cl}^{-}$system has been demonstrated to be mainly responsible for the nonlethal suppression of the activity and mitogen-induced DNA synthesis of NK lymphocytes and for changes in several functions (proliferation, antibody formation, cytolysis) of different lymphocyte types (B, T, NK) [23, 24]. MPO deficient neutrophils and the absence of chloride anion limit this decrease of natural killer cell functions [23]. This functional injury to adjacent immunocompetent cells is most often sublethal, influenced in situ by the number, the state of activation and the proximity of the neutrophils, as well as by the antioxidant potential of the microenvironment. However, the specific effects of MPO on the functions of the lymphocytes need further studies to be more clearly understood.

\section{Interactions with macrophages}

MPO triggers the cytokine production (TNF $\alpha$, Ill, and $\gamma$ IFN) of macrophages [59], in a dose-dependent manner, but the exact mechanism of this induction remains unknown: after internalization of the enzyme via the mannose receptors present on the macrophages, MPO can increase the cytokines production by a direct action or by inducing specific signal transductions for cytokine synthesis [96]. MPO also enhances the cytotoxicity of macrophages by increasing their active oxygen species production, particularly against microorganisms with polysaccharidic capsules $[60,66]$. Macrophages are devoid of MPO, but produce $\mathrm{H}_{2} \mathrm{O}_{2}$ : a trapping of MPO by macrophages can occur when neutrophils are in contact with these cells. At the sites of inflammation, the neutrophils are attracted, stimulated, and can be phagocytosed by the stimulated macrophages; this could occur in the alveoli. This uptake can reinforce the microbicidal activity of macrophages, as described above, and induce the cytotoxicity of macrophages for target cells. 


\section{Interactions with other cells}

When MPO is added to normal neutrophils, it decreases phagocytosis (decreased attachment and ingestion of particles). These data indicate that, apart from being a potent constitutive antimicrobial system, the oxidizing activity of the $\mathrm{MPO} / \mathrm{H}_{2} \mathrm{O}_{2} / \mathrm{Cl}^{-}$system may modulate the inflammatory response by impairing certain receptor-mediated recognition mechanisms of phagocytic cells, which otherwise could elicit inflammatory reactions and tissue injury [99].

It seems that MPO can also interact with numerous other cells such as fibroblasts, erythrocytes, platelets, and endothelial cells. With endothelial cells, an uptake of MPO has been observed when neutrophils are marginated in capillaries, bound to adhesion receptors of endothelial cells, and locally activated, degranulating and releasing MPO in close contact with the endothelium; this internalization of the enzyme, which remains active, can reinforce the endothelium defense against microorganisms, but can also act on the endothelium functions. Co-culture of endothelial cells with neutrophils induces a decrease in the activity of the angiotensin-converting enzyme, which is sensitive to oxidants at the level of the zinc center and the tyrosyl residue of its catalytic center [22]. However, most of the effects of MPO on endothelial or other cells in physiological conditions remain largely unknown and are linked to the activity of the other oxidant species produced by the stimulated neutrophils.

\section{Myeloperoxidase in diseases}

MPO is associated with several diseases, but the mechanisms of these associations remain largely unclear. Circulating antibodies to MPO were associated with glomerulonephritis and systemic vasculitis [63], and a genetic polymorphism of MPO in the promoter region was described to markedly reduce MPO transcription resulting in a reduction of lung cancer risk [62]. MPO gene would also be expressed in microglia and would play a role in the pathogenesis of multiple sclerosis [72]. However, these original results remain to be confirmed by further studies on large number of patients.

\section{MPO in atherosclerosis}

Interest is now increasing in the oxidation theory of atherosclerosis and in the role of $\mathrm{MPO} / \mathrm{H}_{2} \mathrm{O}_{2} / \mathrm{Cl}^{-}$system. Elevated levels of low density lipoproteins (LDL) are considered as a major risk for the development of atherosclerosis, and it is now suggested that LDL must be oxidized to trigger the development of this disease. MPO system plays an important role in atherosclerosis because the hypoxic conditions, resulting from impaired oxygenation, are likely to render the arterial wall acidic favoring chlorination and oxidation. Indeed, MPO is afforded by monocytes and neutrophils infiltrating the intima from the early stage of artherosclerosis [31] and is found in its active form in human artherosclerotic lesions [17] modifying LDL into a high uptake-form for macrophages [34]. This oxidation of LDL contributes to the early stages of atherosclerosis. Oxidized LDL have been recognized in aortas and plasma of humans with established cardiovascular disease. Recently, the in vivo oxidants responsible for the generation of oxidized LDL have been identified as hypochlorite and molecular chlorine, results of the MPO activity. Indeed, activated phagocytes generate chlorinated LDL cholesterol and aminoacid-derived aldehydes [37, 38], and elevated levels of 3-chlorotyrosine and hypochlorite-modified LDL are present in human atherosclerotic lesions [33, 36]. HOCl-modified LDL are detected in both early and advanced atherosclerotic lesions, inside and outside cells. The main target for the LDL oxidation are the aminoacids (mainly tryptophan and lysine) of the apo B with a subsequent aggregation of the LDL [35, 44]. The modification of the protein moiety of LDL is faster than the peroxidation of the lipid part of the molecules. This oxidized Apo B-LDL was recognized by specific antibodies into macrophages, but also in smooth muscle and endothelial cells, and in a cellular areas of connective tissue [33].

\section{MPO deficiency}

MPO deficiency is the most common neutrophilic lysosomal enzyme deficiency. Its frequency has been estimated to be 1 in 2000 to 4000 individuals in the USA [73]. The MPO deficiency can be complete or, most often, partial (50\% reduced amounts as compared to normal subjects). It is of autosomal recessive inheritance and is not accompanied by a deficiency in the activity of peroxidase in eosinophils despite a 70\% homology in the DNA sequences of the 2 enzymes [90]. Recently, mutations were observed in the genes of subjects with MPO deficiency. The MPO genetic defect may involve a failure to synthesize a single precursor peptide, a defective regulation of the synthesis of the 2 separate peptides or an aberration in postsynthetic processing or packaging into the granules. Mutations are often single base pair mutations; some of them have been identified, such as a $\mathrm{C}$ to $\mathrm{T}$ substitution at codon 569 in exon 10, resulting in arginine to tryptophan substitution [52]. So far four mutations have been identified in patients with MPO deficiency: R569W, Y173C, M251T, and 14base deletion in exon 9. Most of the patients with MPO deficiency are compound heterozygotes (different mutations on their paternal and maternal MPO alleles). It remains unclear why some patients develop clinical symptoms while other do not [82].

DeLeo et al. [20] studied the missense mutation in the MPO gene at codon 173 whereby tyrosine is replaced with cysteine (Y173C). In the cells affected by this mutation, 
the precursor MPO was glycosylated, associated with the molecular chaperones (calreticulin and calnexin), acquired heme, but was neither proteolytically processed to mature MPO subunits nor secreted. It was degraded in the endoplasmic reticulum.

The nucleotide substitution in the gene of MPO leading to the replacement of arginine 569 by tryptophan was detected in patients with complete MPO deficiency [52]. This mutation (R569W) leads to the synthesis of apopro-MPO, without heme insertion, resulting in a defective posttranslational processing; active pro-MPO and the mature subunits are not generated from this defective apopro-MPO [74]. Other forms of MPO deficiency have been characterized by mutations leading to the substitution of a threonine by a methionine [88].

Case studies indicate that patients lacking MPO usually do not show any increased susceptibility to infection or altered inflammatory response, in the absence of coexisting conditions such as diabetes mellitus. But individuals with MPO deficiency have a markedly impaired ability to kill fungi such as Candida albicans: the lack of MPO inhibits the extracellular killing of these microorganisms, and, because of their shape, their phagocytosis is limited or impossible [73]. Granulocytes of diabetic patients with MPO deficiency have a partially diminished or an almost nil microbicidal activity with regard to Staphylococcus aureus or to Candida albicans. Moreover, MPO deficiency seems associated to chronic granulomatous disease, and antiMPO-ANCA (autoantibodies to neutrophil cytoplasmic antigens) have been detected in plasma of patients with idiopathic forms of necrotizing glomerulonephritis and necrotizing alveolar capillaritis (idiopathic pulmonary hemorrhage) $[9,10]$.

In contrast, a number of investigators have documented an enhanced phagocytosis and an increased oxidative burst, with an exaggerated superoxide anion production on stimulation in vitro, for MPO-deficient neutrophils [99].

The lack of MPO, thus, appears compensated, explaining that persons lacking MPO activity do not normally suffer from severe infections [30]. The microbicidal activity of neutrophils, thus, seems the consequence of overlapping antimicrobial systems. Indeed, MPO-deficient neutrophils remain able to kill Escherichia coli indicating that nonoxidative microbicidal systems are sufficient for a full microbicidal effect and that MPO contribution would be somewhat redundant. However, MPO normal neutrophils rapidly suppress Escherichia coli DNA synthesis [91], which was not observed for MPO-deficient neutrophils. Some pathogens covered with polysaccharidic capsules re- sistent to proteolytic enzymes and needing a full oxidative system to be inactivated would remain unkilled by MPOdeficient neutrophils.

\section{MPO in acute myeloid leukemias}

In contrast with MPO deficiency, high levels of the enzyme have been observed in acute myeloid or promyelocytic leukemias (AML, APL). It was reported that the MPO gene was translocated from chromosome 17 to 15 , a translocation of which the significance remains unclear, but that would be associated with the high expression of MPO seen in AML [106]. These results remain contested, but it appears that the human MPO gene is in close proximity to the translocation breakpoint in APL and that MPO gene expression is detected in most AMLs [29, 117]. A potential link would exist between MPO genotype (allelic association, gene polymorphism), aberrant MPO expression, and myeloid leukemia. A MPO genotype with an allelic form at -463 would correlate with increased MPO mRNA and would be overrepresented in certain APL and AMLs [86]. Techniques and probes now exist for analyzing MPO expression at the RNA level, which makes possible extensive studies of MPO expression in a wide range of neoplastic and preneoplastic blood disorders $[5,6,105]$.

\section{Conclusion}

MPO plays a main favorable role in host defense by its ability to produce aggressive oxygen and chlorine species deleterious to microorganisms and to act in concert with hydrolytic and proteolytic enzymes within the phagolysosome. Outside this phagocytic vacuole, MPO is far from being an inocuous enzyme, despite the possibility that the enzyme would be rapidly inactivated. When MPO is taken up by macrophages, it plays a beneficial role, helping these cells in the killing of pathogens. However, when released in excess on the endothelium or in alveolar spaces, MPO exerts oxidizing activities leading to essential protein inactivation, cytotoxicity, and development of atherosclerotic lesions. Until now the control of this deleterious activity has remained impossible, since we have no safe specific inhibitors of MPO and since it could be dangerous to inhibit the MPO activity by repressing the neutrophil activation, especially in critically ill patients. 


\section{References}

1. Albrich JM, McCarthy CA, Hurst JK (1981) Biological reactivity of hypochlorous acid: implications for microbicidal mechanisms of leukocyte myeloperoxidase. Proc Natl Acad Sci USA 78:210-214

2. Andrews PC, Krinsky NI (1981) The reductive cleavage of myeloperoxidase in half, producing enzymatically active hemi-myeloperoxidase. J Biol Chem 256: 4211-4218

3. Arndt H, Kubes P, Granger DN (1991) Involvement of neutrophils in ischemia-reperfusion injury in the small intestine. Klin Wochenschr 69: 1056-1060

4. Arnljots K, Olsson I (1987) Myeloperoxidase precursors incorporate heme. J Biol Chem 262: 10430-10433

5. Austin GE, Chan WC, Zhao W, Racine M (1994) Myeloperoxidase gene expression in normal granulopoiesis and acute leukemia. Leuk Lymphoma 15:209-226

6. Austin GE, Zhao WG, Regmi A, Lu JP, Braun GE (1998) Identification of an upstream enhancer containing an AML1 site in the human myeloperoxidase (MPO) gene. Leuk Res 22: 1037-1048

7. Bakkenist ARJ, Wever R, Vulsma T, Plat H, Van Gelder BF (1978) Isolation procedure and some properties of myeloperoxidase from human leukocytes. Biochim Biophys Acta 524:4554

8. Borregaard N, Cowland JB (1997) Granules of the human neutrophilic polymorphonuclear leukocyte. Blood 89:3503-3521

9. Bosch X, Font J, Mirapeix E, Revert L, Ingelmo M, Urbano-Marquez A (1992) Antimyeloperoxidase autoantibody-associated necrotizing alveolar capillaritis. Am Rev Respir Dis 146: 1326-1329

10. Bosch X, Mirapeix E, Font J, Ingelmo M, Revert L (1991) Anti-myeloperoxidase antibodies in crescentic glomerulonephritis. Nephron 59:504-505

11. Britigan BE, Ratcliffe HR, Buettner GR, Rosen GM (1996) Binding of myeloperoxidase to bacteria: effect on hydroxyl radical formation and susceptibility to oxidant-mediated killing. Biochim Biophys Acta 1290: 231-240
12. Carr AC, van den Berg JM, Winterbourn CC (1998) Differential reactivities of hypochlorous and hypobromous acids with purified Escherichia coli phospholipid: formation of haloamines and halohydrins. Biochim Biophys Acta 1392:254-264

13. Carreras MC, Pargament GA, Catz SD, Poderoso JJ, Boveris A (1994) Kinetics of nitric oxide and hydrogen peroxide production and formation of peroxynitrite during the respiratory burst of human neutrophils. FEBS Lett 341:65-68

14. Clark RA, Szot S, Williams MA, Kagan HM (1986) Oxidation of lysine side-chains of elastin by the myeloperoxidase system and by stimulated neutrophils. Biochem Biophys Res Commun 135: 451-457

15. Cochrane CG, Spragg RG, Revak SD, Cohen AB, McGuire WW (1983) The presence of neutrophil elastase and evidence of oxidation activity in bronchoalveolar lavage fluids of patients with adult respiratory distress syndrome. Am Rev Respir Dis 127: 525-527

16. Damas $P$, Nys M, Mathy M, Canivet JL, Ledoux D, Peters JL, Deby G, Lamy M (1997) Cytotoxicity index and neutrophil products in BAL fluid from ventilator-associated pneumonia and ARDS patients. Intensive Care Med 23:S106 (Abstr)

17. Daugherty A, Dunn JL, Rateri DL, Heinecke JW (1994) Myeloperoxidase, a catalyst for lipoprotein oxidation, is expressed in human atherosclerotic lesions. J Clin Invest 94: 437-444

18. Deby-Dupont G, Croisier JL, Camus G, Brumioul D, Mathy-Hartert M, Sondag D, Deby C, Lamy M (1994) Inactivation of $\alpha_{2}$-macroglobulin by activated human polymorponuclear leucocytes. Mediators Inflamm 3:117-123

19. Deby-Dupont G, Deby C, Lamy M (1998) Neutrophil myeloperoxidase: effector of host defense and host damage. In: Vincent JL (ed) Yearbook of Intensive Care and Emergency Medicine. Springer Verlag, Berlin, pp 75-86

20. DeLeo FR, Goedken M, McCormick SJ, Nauseef WM (1998) A novel form of hereditary myeloperoxidase deficiency linked to endoplasmic reticulum/proteasome degradation. J Clin Invest 101:2900-2909

21. Domigan NM, Charlton TS, Duncan MW, Winterbourn CC, Kettle AJ (1995) Chlorination of tyrosyl residues in peptides by myeloperoxidase and human neutrophils. J Biol Chem 270: 16542-16548
22. Eiserich JP, Hristova M, Cross CE, Jones DA, Freeman BA, Halliwell B, Van der Vliet A (1998) Formation of nitric oxide-derived inflammatory oxidants by myeloperoxidase in neutrophils. Nature 301:393-397

23. El-Hag A, Clark RA (1987) Immunosuppression by activated human neutrophils. J Immunol 139:2406-2413

24. El-Hag A, Lipsky PE, Bennett M, Clark RA (1986) Immunomodulation by neutrophil myeloperoxidase and hydrogen peroxide: differential susceptibility of human lymphocyte functions. J Immunol 136:3420-3424

25. Everse E (1998) The structure of heme proteins compounds I and II: some misconceptions. Free Rad Biol Med 24: 1338-1346

26. Faymonville ME, Pincemail J, Duchateau J, Paulus JM, Adam A, DebyDupont G, Deby C, Albert A, Larbuisson R, Limet R, Lamy M (1991) Myeloperoxidase and elastase as marker of leukocyte activation during cardiopulmonary bypass in human. J Thorac Cardiovasc Surg 102:309-317

27. Fenna R, Zeng J, Davey C (1995) Structure of the Green Heme in myeloperoxidase. Arch Biochem Biophys 316:653-656

28. Floris R, Piersma S, Yang G, Jones P, Wever R (1993) Interaction of myeloperoxidase with peroxynitrite. A comparison with lactoperoxidase, horseradish peroxidase and catalase. Eur J Biochem 215:767-775

29. Ferrari S, Tagliafico E, Ceccherelli G, Selleri L, Calabretta B, Donelli A, Temperani P, Sarti M, Sacchi S, Emilia G (1989) Expression of the myeloperoxidase gene in acute and chronic myeloid leukemias: relationship to the expression of cell cycle-related genes. Leukemia 3:423-430

30. Gerber CE, Kuci S, Zipfel M, Niethammer D, Bruchelt G (1996) Phagocytic activity and oxidative burst of granulocytes in persons with myeloperoxidase deficiency. Eur J Clin Chem Clin Biochem 34:901-908

31. Gerrity RG (1981) The role of the monocyte in atherogenesis. I. Transition of bloodborne monocytes into foam cells in fatty lesions. Am J Pathol 103:181-190

32. Hällgren R, Samuelsson T, Venge $P$, Modig J (1987) Eosinophil activation in the lung is related to lung damage in adult respiratory distress syndrome. Am Rev Respir Dis 135: 639-642

33. Hazell LJ, Arnold L, Flowers D, Waeg G, Malle E, Stocker R (1996) Presence of hypochlorite-modified proteins in human atherosclerotic lesions. J Clin Invest 87: 1535-1544 
34. Hazell LJ, Stocker R (1993) Oxidation of low-density lipoprotein with hypochlorite causes transformation of lipoprotein into a high-uptake form for macrophages. Biochem J 290: 165-172

35. Hazell LJ, Van den Berg JJM, Stocker R (1994) Oxidation of low density lipoprotein by hypochlorite causes aggregation that is mediated by modification of lysine residues rather than lipid oxidation. Biochem J 304:27-34

36. Hazen SL, Heinecke JW (1997) 3-Chlorotyrosine, a specific marker of myeloperoxidase-catalyzed chlorination is markedly elevated in low density lipoprotein isolated from human atherosclerotic intima. J Clin Invest 99: 2075-2081

37. Hazen SL, Hsu FF, d'Avignon A, Heinecke JW (1998) Human neutrophils employ myeloperoxidase to convert alpha-amino acids to a battery of reactive aldehydes: a pathway for aldehyde generation at sites of inflammation. Biochemistry 37:68646873

38. Hazen SL, Hsu FF, Duffin K, Heinecke JW (1996) Molecular chlorine generated by the myeloperoxidasehydrogen peroxide-chloride system of phagocytes converts low density lipoprotein cholesterol into a family of chlorinated sterols. J Biol Chem 271: 23080-23088

39. Hazen SL, Hsu FF, Mueller DM, Crowley JR, Heinecke JW (1996) Human neutrophils employ chlorine gas as an oxidant during phagocytosis. J Clin Invest 98: 1283-1289

40. Heinecke JW, Li W, Daehnke HL, Goldstein JA (1993) Dityrosine, a specific marker of oxidation, is synthetized by the myeloperoxidase-hydrogen peroxide system of human neutrophils and macrophages. J Biol Chem 268:4069-4077

41. Heinecke JW, Li W, Francis GA, Goldstein JA (1993) Tyrosyl radical generated by myeloperoxidase catalyzes the oxidative cross-linking of proteins. J Clin Invest 91:2866-2872

42. Inazawa J, Inoue $\mathrm{K}$, Nishigaki $\mathrm{H}$, Tsuda S, Taniwaki M, Misawa S, Abe $\mathrm{T}$ (1989) Assignment of the human myeloperoxidase gene (MPO) to bands q21.3-q23 of chromosome 17. Cytogenet Cell Genet 50: 135-136

43. Jacquet A, Deby C, Mathy M, Moguilewsky N, Deby-Dupont G, Thirion A, Goormaghtigh E, Garcia-Quintana L, Bollen A, Pincemail J (1991) Spectral and enzymatic properties of human recombinant myeloperoxidase: comparison with the mature enzyme. Arch Biochem Biophys 291: 132-138
44. Jerlich A, Fabjan JS, Tschabuschnig S, Smirnova A, Horakova L, Hayn M, Auer H, Guttenberger H, Leis HJ, Tatzber F, Waeg G, Schaur RS (1998) Human low density lipoprotein as a target of hypochlorite generated by myeloperoxidase. Free Rad Biol Med 24: 1139-1148

45. Johnson K, Gemperlein I, Hudson S, Shane S, Rovera G (1989) Complete nucleotide sequence of the human myeloperoxidase gene. Nucleic Acids Res 17: 7985-7986

46. Kanofsky JR, Wright J, Miles-Richardson GE, Tauber A (1984) Biochemical requirements for singlet oxygen production by purified human myeloperoxidase. J Clin Invest 74 : 1489-1495

47. Kawano S, Tatsumi E, Yoneda N, Nagata S, Yamaguchi N (1993) Suppression of gene expression of myeloperoxidase (MPO) by gamma-interferon (IFN-gamma) in HL60 cells. Lymphokine Cytokine Res 12:81-85

48. Kettle AJ (1995) Neutrophils convert tyrosin residues in albumin to chlorotyrosine. FEBS Lett 379: 103-106

49. Kettle AJ, Gedye CA, Winterbourn C (1993) Superoxide is an antagonist of antiinflammatory drugs that inhibit hypochlorous acid production by myeloperoxidase. Biochem Pharmacol 45:2003-2010

50. Kettle AJ, Winterbourn CC (1994) Superoxide-dependent hydroxylation by myeloperoxidase. J Biol Chem 269: 17146-17151

51. King CC, Jefferson MM, Thomas EL (1997) Secretion and inactivation of myeloperoxidase by isolated neutrophils. J Leukoc Biol 61:293-302

52. Kizaki M, Miller CW, Selsted ME, Koeffler HP (1994) Myeloperoxidase ,(MPO) gene mutation in hereditary MPO deficiency. Blood 83: 19351940

53. Klebanoff SJ, Clark RA (1975) Hemolysis and iodination of erythrocyte components by a myeloperoxidasemediated system. Blood 45:699-707

54. Klebanoff SJ, Waltersdorph AM, Rosen H (1984) Antimicrobial activity of myeloperoxidase. Meth Enzymol 105:399-403

55. Konishi H, Tanaka M, Takemura Y, Matsuzaki H, Ono Y, Kikkawa U, Nishizuka Y (1997) Activation of protein kinase $\mathrm{C}$ by tyrosine phosphorylation in response to $\mathrm{H}_{2} \mathrm{O}_{2}$. Proc Natl Acad Sci USA 94: 11233-11237

56. Kooter IM, Moguilevsky N, Bollen A, Sijtsema NM, Otto C, Wever R (1997) Site-directed mutagenesis of Met243, a residue of myeloperoxidase involved in binding of the prosthetic group. J Biol Inorg Chemistry 2: 191-197
57. Koppenol WH (1994) Thermodynamic considerations on the formation of reactive species from hypochlorite, superoxide and nitrogen monoxide. Could nitrosyl chloride be produced by neutrophils and macrophages? FEBS Lett 347:5-8

58. Lamy M, Mathy-Hartert M, DebyDupont G (1996) Neutrophil-induced oxidative stress. In: Vincent JL (ed) Yearbook of Intensive Care and Emergency Medicine. Springer Verlag, Berlin, pp 83-93

59. Lefkowitz DL, Mills K, Morgan M, Lefkowitz S (1992) Macrophage activation and immuno-modulation by myeloperoxidase. Proc Soc Exp Biol Med 199:204-210

60. Lincoln JA, Lefkowitz DL, Cain T, Castro A, Mills KC, Lefkowitz SS, Moguilevsky N, Bollen A (1995) Exogenous myeloperoxidase enhances bacterial phagocytosis and intracellular killing by macrophages. Infection and Immunity 63:3042-3047

61. Locksey RM, Nelson C, Fankhauser JE, Klebanoff SJ (1987) Loss of granule myeloperoxidase during in vitro culture of human monocytes correlates with decay in antiprotozoa activity. Am J Trop Med Hyg 36:541-548

62. London SJ, Lehman TA, Taylor JA (1997) Myeloperoxidase genetic polymorphism and lung cancer risk. Cancer Res 57:5001-5003

63. Longhurst C, Ehrenstein MR, Leaker B, Stevenson FK, Spellerberg M, Chapman C, Latchmen D, Isenberg DA, Cambridge G (1996) Analysis of immunoglobin variable region genes of a human IgM anti-myeloperoxidase antibody derived from a patient with vasculitis. Immunology 87:334338

64. Matheson NR, Travis J (1985) Differential effects of oxidizing agents on human plasma $\alpha_{1}$-proteinase inhibitor and human neutrophil myeloperoxidase. Biochemistry 24: 1941-1945

65. Mathy-Hartert M, Deby-Dupont G, Deby C, Jadoul L, Vandenberghe A, Lamy M (1995) Cytotoxicity induced by neutrophil myeloperoxidase towards human endothelial cells: protection by ceftazidime. Mediators Inflamm $4: 1-7$

66. Mathy-Hartert M, Deby-Dupont G, Melin P, Lamy M, Deby C (1996) Cultured macrophages acquire a bactericidal activity against Pseudomonas aeruginosa after incorporation of myeloperoxidase. Experientia 52:1-8 
67. Miyasaki KT, Wilson ME, Cohen E, Jones PC, Genco RJ (1986) Evidence for and partial characterization of three major and three minor chromatographic forms of human neutrophil myeloperoxidase. Arch Biochem Biophys 246:751-764

68. Miyasaki KT, Zambon JJ, Jones CA, Wilson ME (1987) Role of high-acidity binding of human neutrophil myeloperoxidase in the killing of Actinobacillus actinomycetemconcomitans. Infect Immun 55: 1029-1036

69. Moguilevsky N, Garcia-Quintana L, Jacquet A, Tournay C, Fabry L, Piérard L, Bollen A (1991) Structural and biological properties of human recombinant myeloperoxidase produced by Chinese hamster ovary cell lines. Eur J Biochem 197:605-614

70. Morishita K, Kubota N, Asano S, Kaziro Y, Nagata S (1987) Molecular cloning and characterization of cDNA for human myeloperoxidase. J Biol Chem 262:3844-3851

71. Murao S, Stevenc FJ, Ito A, Huberman E (1988) Myeloperoxidase: a myeloid cell nuclear antigen with DNA-binding properties. Proc Natl Acad Sci 85: 1232-1236

72. Nagra RM, Becher B, Tourtellotte WW, Antel JP, Gold D, Paladino T, Smith RA, Nelson JR, Reynolds WF (1997) Immunohistochemical and genetic evidence of myeloperoxidase involvement in multiple sclerosis. J Neuroimmunol 78:97-107

73. Nauseef WM (1988) Myeloperoxidase deficiency. Hemat Oncol Clin North Am 2:135-158

74. Nauseef WM, Cogley M, McCormick S (1996) Effect of the R569W missense mutation on the biosynthesis of myeloperoxidase. J Biol Chem 271: 9546-9549

75. Olsen RL, Little C (1984) Studies on the subunits of myeloperoxidase. Biochem J 222:701-704

76. Olsson I, Olofsson T, Odeberg H (1972) Myeloperoxidase-mediated iodination in granulocytes. Scand J Haemat 9:483-491

77. Olsson I, Persson AM, Strömberg K (1984) Biosynthesis, transport and processing of myeloperoxidase in the human leukaemic promyelocytic cell line HL-60 and normal marrow cells. Biochem J 223:911-920
78. Orita T, Shimozaki K, Murakami H, Nagata S (1997) Binding of NF-Y transcription factor to one of the ciselements in the myeloperoxidase gene promoter that responds to granulocyte colony-stimulating factor. J Biol Chem 272:23216-23223

79. Pacht ER, Timerman AP, Lykens MG, Merola AJ (1991) Deficiency of alveolar fluid glutathione in patients with sepsis and the adult respiratory distress syndrome. Chest 100:13971403

80. Pember SO, Fuhrer-Kruesi SM, Barnes KC, Kinkade JM (1982) Isolation of three native forms of myeloperoxidase from human polymorphonuclear leukocytes. FEBS Lett 140: 103-108

81. Pember SO, Shapira R, Kinkade JM (1983) Multiple forms of myeloperoxidase from human neutrophilic granulocytes: evidence for differences in compartmentalization, enzymatic activity and subunit structure. Arch Biochem Biophys 221:391-403

82. Petrides PE (1998) Molecular genetics of peroxidase deficiency. J Mol Med 76: 688-698

83. Prütz WA (1996) Hypochlorous acid interactions with thiols, nucleotides, DNA, and other biological substrates. Arch Biochem Biophys 332: 110-120

84. Rakita RM, Micher BR, Rosen H (1990) Differential inactivation of Escherichia coli membrane dehydrogenases by a myeloperoxidase-mediated antimicrobial system. Biochemistry 29: 1075-1080

85. Ramos CL, Pou S, Britigan BE, Cohen MS, Rosen GM (1992) Spin trapping evidence for myeloperoxidasedependent hydroxyl radical formation by human neutrophils and monocytes. J Biol Chem 267:8307-8312

86. Reynolds WF, Chang E, Douer D, Ball ED, Kanda V (1997) An allelic association implicates myeloperoxidase in the etiology of acute promyelocytic leukemia. Blood 90:27302737

87. Ricou B, Nicod L, Lacraz S, Welgus HG, Suter PM, Dayer JM (1997) Matrix metalloproteinases and TIMP in acute respiratory distress syndrome. Am J Respir Crit Care Med 154:346352

88. Romano M, Dri P, Dadalt L, Patriarca P, Baralle FE (1997) Biochemical and molecular characterization of hereditary myeloperoxidase deficiency. Blood 90:4126-4134

89. Rosen H, Klebanoff SJ (1985) Oxidation of microbial iron-sulfur centers by the myeloperoxidase- $\mathrm{H}_{2} \mathrm{O}_{2}$-halide antimicrobial system. Infect Immun 47: 613-618
90. Rosen H, Michel BR (1997) Redundant contribution of myeloperoxidase-dependent systems to neutrophil-mediated killing of Escherichia coli. Infect Immun 65:7173-7178

91. Rosen H, Orman J, Ratika RM, Michel BR, Van-Devanter DR (1990) Loss of DNA interactions and cessation of DNA synthesis in myeloperoxidasetreated Escherichia coli. Proc Natl Acad Sci 87: 10048-10052

92. Sampson JB, Ye Y, Rosen H, Beckman JS (1998) Myeloperoxidase and horseradish peroxidase catalyze tyrosine nitration in proteins from nitrite and hydrogen peroxide. Arch Biochem Biophys 356:207-213

93. Schieven GL (1997) Tyrosine phosphorylation in oxidative stress. In: Forman HJ, Cadenas E (eds) Oxidative Stress and Signal Transduction. Chapman and Hall, New York, pp 181- 199

94. Schoonbroodt S, Legrand-Poels S, Best-Belpomme M, Piette J (1997) Activation of the NF- $\kappa \mathrm{B}$ transcription factor in a T-lymphocytic cell line by hypochlorous acid. Biochemical J 321:777-785

95. Schulze-Osthoff K, Bauer M, Vogt M, Wesselborg S, Baeuerle PA (1997) Reactive oxygen intermediates as primary signals and second messengers in the activation of transcription factors. In: Forman HJ, Cadenas E (eds) Oxidative Stress and Signal Transduction. Chapman and Hall, New York, pp 32-51

96. Schwartz MD, Moore EE, Moore FA, Shenkar R, Moine P, Haenel JB, Abraham E (1996) Nuclear factor- $\kappa B$ is activated in alveolar macrophages from patients with acute respiratory distress syndrome. Crit Care Med 24: 1285-1292

97. Shepperd VL, Hoidal J (1990) Clearance of neutrophil-derived myeloperoxidase by the macrophage mannose receptor. Am J Respir Cell Mol Biol 2:335-340

98. Spear N, Estevez AG, Radi F, Beckman JS (1997) Peroxynitrite and cell signaling. In: Forman HJ, Cadenas E (eds) Oxidative Stress and Signal Transduction. Chapman and Hall, New York, pp 239:259

99. Stendahl O, Coble BI, Dahlgren C, Hed J, Molin L (1984) Myeloperoxidase modulates the phagocytic activity of polymorphonuclear neutrophil leukocytes. Studies with cells from a myeloperoxidase-deficient patient. J Clin Invest 73:366-373 
100. Suter PM, Suter S, Girardin E, RouxLombard P, Grau GE, Dayer JM (1992) High bronchoalveolar levels of tumor necrosis factor and its inhibitors, interleukin-1, interferon, and elastase, in patients with adult respiratory distress syndrome after trauma, shock, or sepsis. Am Rev Respir Dis 145: 1016-1022

101. Taurog A, Dorris ML (1992) Myeloperoxidase-catalyzed iodination and coupling. Arch Biochem Biophys 296:239-246

102. Taylor KL, Guzman GS, Burgess CA Kinkade JM (1990) Assembly of dimeric myeloperoxidase during posttranslational maturation in human leukemic HL-60 cells. Biochemistry 29: 1533-1539

103. Tobler A, Koeffler HP (1991) Myeloperoxidase: localization, structure, and function. In: Harris GR (ed) Blood Cell Biochemistry 3. Lymphocytes and Granulocytes. Plenum Press, New York, pp 255-288

104. Tobler A, Miller CW, Johnson KR, Selsted ME, Rovera G, Koeffler HP (1988) Regulation of gene expression of myeloperoxidase during myeloid differentiation. J Cell Physiol 136: 215-225

105. Traweek ST, Liu J, Braziel RM, Johnson RM, Byrnes RK (1995) Detection of myeloperoxidase gene expression in minimally differentiated acute myelogenous leukemia (AML-M0) using in situ hybridization. Diagn Mol Pathol 4:212-219
106. Weil SC, Rosner GL, Reid MS, Crisholm RL, Lemons RS, Swanson MS, Carrino JJ, Diaz MO, Le Beau MM (1988) Translocation and rearrangement of myeloperoxidase gene in acute promyelocytic leukemia. Science 240:790-792

107. Weiland JE, Davis WB, Holter JF, Mohammed JR, Dorinsky PM, Gadek JE (1986) Lung neutrophils in the adult respiratory distress syndrome. Am Rev Respir Dis 133:218-225

108. Weiss SJ (1989) Tissue destruction by neutrophils. New Engl J Med 320: 365-376

109. Weiss SJ, Peppin G, Ortiz X, Ragsdale C, Test ST (1985) Oxidative autoactivation of latent collagenase by human neutrophils. Science 227:747749

110. Winterbourn CC (1985) Comparative reactivities of various biological compounds with myeloperoxidase-hydrogen peroxide-chloride, and similarity of the oxidant to hypochlorite. Biochim Biophys Acta 840:204-210

111. Winterbourn CC, Brennan SO (1997) Characterization of the oxidation products of the reaction between reduced glutathione and hypochlorous acid. Biochem J 326: 87-92

112. Winterbourn CC, Garcia RC, Segal AW (1985) Production of the superoxide adduct of myeloperoxidase (compound III) by stimulated human neutrophils and its reactivity with hydrogen peroxide and chloride. Biochem J 228:583-592

113. Wright CD, Nelson RD (1988) Candidacidal activity of myeloperoxidase: characterization of myeloperoxidase-yeast complex formation. Biochem Biophys Res Commun 154: 809-817
114. Wright J, Bastian N, Davis TA, Zuo C, Yoshimoto S, Orme-Johnson WH, Tauber AI (1990) Structural characterization of the isoenzymatic forms of human myeloperoxidase: evaluation of the iron-containing prosthetic group. Blood 75:238-241

115. Yamada M, Yoshida M, Hashinaka K (1993) Identification of transcriptional cis-elements in introns 7 and 9 of the myeloperoxidase gene. J Biol Chem 268: 13479-13485

116. Zabucchi G, Soranzo MR, Menegazzi R, Bertoncin P, Nardon E, Patriarca P (1989) Uptake of human eosinophil peroxidase and myeloperoxidase by cells involved in the inflammatory process. J Histochem Cytochem 37:499-508

117. Zaki SR, Austin GE, Swan DC, Hooper WC, Greer PW, Evatt BL, Chan WC (1990) Studies of myeloperoxidase gene expression at the cellular level by in situ hybridization. Leukemia 4:813-818

118. Zhao WG, Regmi A, Austin ED, Braun JE, Racine M, Austin GE (1996) Cis-elements in the promoter region of the human myeloperoxidase (MPO) gene. Leukemia 10: 1089-1093 